\title{
Dividend Announcement and Market Efficiency- An Empirical Study on Service Sector Companies Listed in BSE
}

\author{
Rane Anjali* and Guntur Anjana Raju \\ ${ }^{1}$ Assistant Professor and HOD, Department of Commerce and Management, Government Arts and Science \\ College, Karwar, India \\ ${ }^{2}$ Professor, HOD, Department of Commerce, Goa University, Goa, India
}

\begin{abstract}
Dividend Policy is a crucial decision area in the field of corporate finance and informational efficiency of the market has always been an area of vital interest for financial economists. The literature review documented that in imperfect capital markets with information asymmetries, the dividend announcement affects shareholder wealth. However, very few attempts have been made so far to know dividend behavior of Service sector firms in India. The present study is a little research effort in this direction. This study analyses if the announcements of dividend of stocks listed in Bombay Stock Exchange conveys any information. Fulfilling the study, we calculated the average abnormal return by applying the event study methodology. Daily stock data of 193 firms with market model adjustments on 2436 dividend announcements were used for the period 2000 to 2016 to analyze market efficiency. This study reports stock price reactions of banking, health care, IT and realty sector surrounding 21 days event window of the dividend announcement. The results found mixed results with majority of the firms having presence of informational efficiency in Indian service sector. In Realty sectors stock price reaction to dividend announcement is not statistically significant whereas for other three sectors, Banking, IT and Healthcare, it is significant.
\end{abstract}

Keywords: Dividend Signaling, Market Efficiency, Indian Service sector, Event study, Abnormal Return

\section{Introduction}

Shareholders wealth maximization as measured by the price of common stock is the ultimate goal of financial management. It can be achieved by giving the shareholders a fair dividend on their investments. The earlier research shows that the stock price usually increases whenever there is increase in the dividend payments. M\&M, (1968) found that dividend announcement decreases results in abnormal negative returns, and announcement of dividend increase makes abnormal positive returns and thus, dividend payout is a signaling effect resulting in sharp fall or rise in stock price. Investors consider dividend as source of income as well as a signal of firm's future performances. Managers often use dividend increase as signal to outside shareholders to convey positive news about the company that in return cause increase in the stock price. As investors prefer present dividend more than future capital gains to avoid risk of uncertainty, though required rate of return and internal rate of return are equal, there is a direct relationship between market value of share and dividend policy (Gordon, 1962).

*Email: raneanjali@yahoo.co.in 
The objective of this study is to examine implications of dividend announcement in Indian IT, Banking, Realty and Health care sector. Service sector is fastest growing sectors in the India, envisaging various dimensions of growth and globalization, achieving new milestones over the last two decade. The growth impetus gained by the overall economy since the late 1990 s to great extent can be owed to the service sector in specific. In this paper, we tried to analyze, whether stock price reacts to the announcement of dividend in different service sectors industries such as IT, Healthcare, Banking and Realty in Bombay Stock Exchange.

The research is divided in to four sections, where in the first Section describes theoretical background and literature review. In Section 2, data and methodology is presented. In Section 3, empirical results of the event study in Service sector measured in terms of abnormal earning are analysed. ANOVA's and t-test are used. Section 4 concludes the paper.

\subsection{Literature Review}

Dividend irrelevance theory (Miller and Modigliani (M\&M), 1961) and dividend relevance theory are the two schools of thought of dividend policy. Asymmetric information problem resulted in development of the Signaling Theory. The dividend relevance doctrine was supported by Gordon $(1962,1963)$ and Walter (1963). The cash flow signaling theory was developed by researchers such as Bhattacharya (1979, 1980), Easterbrook (1984), John and Williams (1985) and Miller and Rock (1985) and proved that dividend changes are clear cut signals about the current and future returns, sent purposively at some costs by management to stockholders. Aharony etal; (1980), Kwan (1981), Eades (1982), Jensen (1992), Woolridge (1982) used the dividend announcement made in segregation of other firm reports and found a significant positive relation between stock return and the dividend change announcement.

According to John Lintner (1956) "managers increase firm's dividend payout when they are confident that the firm's can sustain its future returns at a consistently higher level and firms to consider relatively stable optimal long-term dividend payout ratios".
Bhattacharya (1979), John etal; (1985), and Miller etal; (1985) put forward Signalling hypothesis, which is based on assumptions that there is asymmetric information between managers (insiders) and shareholders (outside investors). The information about current and future cash flows of companies is hidden in dividend and hence, managers have stimulus to communicate inside information through dividend payments in order to close the information gap to the market. The rise in dividend will be considered as good news and the market will react to dividend change announcement and increase share prices accordingly. Equivalently, announcement of dividend cut suggests unfavorable prospects and will lead to fall in the firm's share price.

Fama (1965) proposed three types of Efficient Market Hypothesis (EMH) hypothesis: (i) weak, (ii) semistrong, and (iii) strong. According to Fama (1965) "the market efficiency in weak form suggests that current stock prices reflect all past information and changes in stock prices are arbitrary. Hence, based on past information investor cannot yield above average returns. The informational efficiency in semi-strong form states that material public information is incorporated in current stock prices and hence proposes that stock prices give back all the publicly available information instantaneously and accurately. Finally, the strong form of market efficiency suggests that as current stock prices absorb all material nonpublic information, insider trading will not lead to any fruitful consequences". The dividend puzzle on importance of dividend announcement and its impact on stock returns based on various form of market efficiency argument is one of the most relevant corporate events and get concentration of academicians and investors to conduct event studies to examine the resulting impact.

\section{Data and Methodology}

We analyzed the stock price behavior of the selected companies in various service sectors surrounding 20 days of the date of dividend announcement to find out the impact of the Dividend announcement on the stock prices. Null hypothesis states that Indian stock market has strong form of market efficiency and hence, announcement of dividend does not have any 
significant impact on the stock price movement of the companies listed in BSE. Symbolically,

Ho: Service Sector Stocks listed in BSE does not have impact of dividend announcement.

\subsection{Data Selection and Sample}

The study considers all the 193 companies which have announced dividend during the year 2001 to 2016 and listed in Bombay Stock Exchange. This time span is reflective of all economic conditions and hence, the results is not specific to anyone stage in the business cycle. It coincides with spells of boom, recession and recovery in the Indian economy. The Data is collected from BSE website. The three sets of data used in the study consist of dividend announcement made by the sample companies, daily adjusted closing share prices for the period covered by this study and S\&P BSE Healthcare, IT, Banking and Realty Index of share prices compiled and published by the BSE on daily basis. The dividend announcements of firms having price sensitive information during the event window of - 10 days to +10 days such as announcement of bonus shares, right shares, stock splits special dividend which are referred as 'contaminated events'(Ali, et al., 2010) were dropped. Final observation considered is $\mathbf{2 4 3 6}$ from available 2785 observations.

\subsection{Methodology - Event Study Approach}

We applied standard event-study methodology to find the share price reaction to the dividend announcement. This method uses data of capital market to measure the impact of a specific event on the stock prices. It is important in the event study to identify the period over which the prices of relevant financial instruments will be examined which is referred to as 'event window' (Rony, et al., 1997). An event window equal to 21 days is set in our study. The dividend announcement date is defined as $t=0$, before the event window of 10 days as 'pre-event window' and after the event window of 10 days as 'post- event window'. To identify any market reaction to the event each firm's observed event period returns are compared to the market's return. We have employed market model to estimate Expected returns.
Mathematically, the Market model is expressed as:

Average Abnormal Return (AAR) $=\mathrm{AR}_{(\text {(it) }}-\mathrm{E}\left(\mathrm{R}_{(\mathrm{it})}\right)$, $t=(-10,-1 \ldots \ldots .1,10)$

Rerurn on Security or $\left(\mathrm{R}_{\text {(it) }}\right)=\left(\mathrm{P}_{(\text {itt }}-\mathrm{P}_{(\text {it) }}{ }_{-1}\right) / \mathrm{P}_{\mathrm{it}}{ }^{-}{ }_{1}$

Return on Market or $\left(\mathrm{R}_{\mathrm{mt}}\right)=\left(\mathrm{I}_{\mathrm{t}}-\mathrm{I}_{\mathrm{t}-1}\right) / \mathrm{I}_{\mathrm{t}-1}$

$\mathrm{R}_{(\text {it) }}$ is changes in Stock Price. i.e; $\mathrm{P}_{\mathrm{it}}$ is the adjusted closing price of the shares ' $i$ ' on day $t$.

$\mathrm{P}_{\text {(it) }}-{ }_{1}$ is the closing price of shares $\mathrm{i}$ on day $\mathrm{t}-1$ and Expected return on security i.e; $E\left(\mathrm{R}_{\text {(it) }}\right)=\square \mathrm{i}+\square \mathrm{iRmt}$ + eit for ' $\mathrm{i}$ ' $=1 \ldots \mathrm{N}$

Where,

$\mathrm{E}\left(\mathrm{R}_{(\mathrm{it})}\right)=$ ' $i$ ' during time period ' $\mathrm{t}$ '

$\square i=$ Alpha coefficient (Intercept) of ' $i$ ' th security $\square \boldsymbol{i}=$ Beta coefficient (Slope) of ' $i$ ' th security

Expected return on index $=\mathrm{R}_{\mathrm{mt}}$ (Ex; S\&P BSE IT Index) during period ' $t$ '.

Ordinary Least Square estimates are obtained from regressions of firm $i$ 's daily returns over the market return in the estimation window from $t=-121$ till $t=$ 11. The two measures of abnormal returns used are, the AAR on the announcement day, AAR0 and Cumulative Average Abnormal returns, CAAR-10 to +10 , measured over the 21-day interval from $t=-10$ till $t=+10$. The standardized cross-sectional $t$ statistic proposed by Boehmer, et al., (1991) has been used measure the statistical significance of these returns.

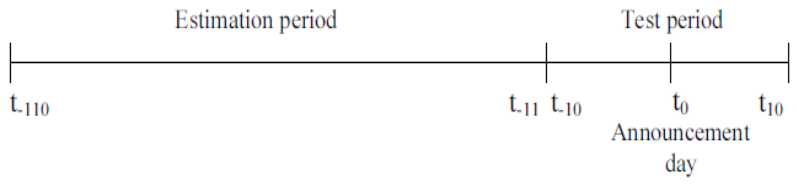

Diagram showing Event Study Methodology

\section{Empirical Results}

To investigate the impact of dividend announcement empirical results in this study are obtained with the help of the event study methodology. As shown in the below tables for each of the four sector under the study, the average abnormal returns and cumulative abnormal returns were studied considering dividend announcement date for 21 days event window comprising 10 days 
prior/post to dividend announcement. Nearer to the announcement day, t-test value on AAR in the pre and post event period for each sector show that they are significant at 5\% level.

\subsection{Banking Sector}

Leakages of information regarding dividend announcements before officially announcement of dividend to insiders or promoters might influence returns on stock. Thus, in case of a "good news" announcement share prices start to rise days before the official dividend announcement.

The above table reveals that abnormal return generated on the day of dividend announcement, $2^{\text {nd }}$ and $3^{\text {rd }}$ day post announcement are statistically significant at $5 \%$ level. The cumulative abnormal return captures the firm specific stock movement for an entire window period. The table depicts positive returns in pre announcement and negative returns post announcement as the market response to dividend announcement.

The post event period in above Figure 1, fall of CAAR reflects high expectation and rational reaction to the disclosure of dividend announcement information. The magnitude of reaction is instantaneous, unbiased and validates significantly to the efficiency of stock market.

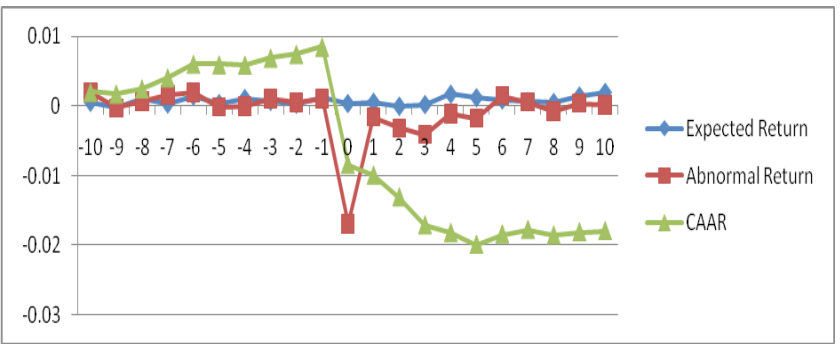

Figure 1. Banking sector market reaction to dividend announcement.

\subsection{Health Sector}

A cumulative abnormal return (CAAR) is better indicator of impact of dividend announcement release which is calculated as total of all abnormal returns over the window period. The below table depicts, Average abnormal return and Cumulative abnormal return are negative post announcement indicating reaction to the dividend announcement and stock market efficiency.

The tables indicates that pre announcement $6^{\text {th }}, 5^{\text {th }}$ and 3rd day abnormal returns are statistically significant and also on the day of announcement as well as post announcement $3^{\text {rd }}, 5^{\text {th }}$ and $8^{\text {th }}$ day returns are statistically significant at $5 \%$ level of significance.

In the Figure 2, the trend shows a reversal from the dividend announcement day signaling impact of

Table 1. Expected return, average abnormal return, cumulative AAR, t test value

\begin{tabular}{|c|c|c|c|c|c|c|c|c|c|}
\hline \multicolumn{5}{|c|}{ Pre Announcement Event Window } & \multicolumn{5}{|c|}{ Post Announcement Event Window } \\
\hline Day & $E\left(R_{i t}\right)$ & AAR & CAAR & T test & Day & $E\left(R_{i t}\right)$ & AAR & CAAR & T test \\
\hline-10 & 0.000535 & 0.001985 & 0.001985 & 2.008 & 0 & & -0.01692 & -0.00842 & $-12.957^{\star *}$ \\
\hline-9 & -0.00022 & -0.00026 & 0.00172 & -.286 & 1 & 0.000535 & -0.00153 & -0.00995 & -1.554 \\
\hline-8 & 0.001097 & 0.000732 & 0.002453 & .743 & 2 & $-2.5 \mathrm{E}-05$ & -0.00314 & -0.01309 & $-3.259^{\star \star}$ \\
\hline-7 & 0.000301 & 0.0016 & 0.004053 & 1.733 & 3 & 0.000215 & -0.00405 & -0.01713 & $-4.215^{\star \star}$ \\
\hline-6 & 0.001411 & 0.001968 & 0.006021 & 2.197 & 4 & 0.001668 & -0.0011 & -0.01824 & -.985 \\
\hline-5 & 0.000358 & $-9.6 \mathrm{E}-05$ & 0.005925 & -.096 & 5 & 0.001184 & -0.00171 & -0.01995 & -1.738 \\
\hline-4 & 0.001055 & $-4.5 \mathrm{E}-05$ & 0.00588 & -.049 & 6 & 0.000864 & 0.001512 & -0.01843 & 1.352 \\
\hline-3 & 0.000666 & 0.001018 & 0.006899 & 1.086 & 7 & 0.000636 & 0.000633 & -0.0178 & .608 \\
\hline-2 & 0.000258 & 0.000541 & 0.00744 & .552 & 8 & 0.000509 & -0.00079 & -0.01859 & -.881 \\
\hline-1 & 0.001129 & 0.001055 & 0.008495 & 1.070 & 9 & 0.001424 & 0.000454 & -0.01813 & .458 \\
\hline 0 & 0.000363 & -0.01692 & -0.00842 & $-12.957^{\star \star}$ & 10 & 0.001927 & 0.000177 & -0.01795 & .198 \\
\hline
\end{tabular}

${ }^{* \star}$ denotes Statistical Significance at $5 \%$ level $(p<.05)$ using 2 tailed test. 
Table 2. Expected return, average abnormal return, cumulative AAR, $t$ test value

\begin{tabular}{|c|c|c|c|c|c|c|c|c|c|}
\hline \multicolumn{5}{|c|}{ Pre Announcement } & \multicolumn{5}{|c|}{ Post Announcement } \\
\hline Days & $E\left(R_{i t}\right)$ & AAR & CAAR & T test & Days & $E\left(R_{i t}\right)$ & AAR & CAAR & T test \\
\hline-10 & 0.001305 & 0.000734 & 0.000734 & .600 & 0 & 0.001102 & -0.01525 & 0.001675 & $-2.904^{\star \star}$ \\
\hline-9 & 0.001362 & 0.002529 & 0.003264 & 1.735 & 1 & 0.001168 & -0.00244 & -0.00077 & .378 \\
\hline-8 & 0.00122 & 0.000743 & 0.004007 & 1.299 & 2 & 0.001089 & -0.00175 & -0.00251 & .557 \\
\hline-7 & 0.001159 & 0.000939 & 0.004946 & 1.184 & 3 & 0.00116 & 0.002236 & -0.00028 & $2.982^{\star \star}$ \\
\hline-6 & 0.001199 & 0.003024 & 0.00797 & $2.344^{\star \star}$ & 4 & 0.00124 & 0.001009 & 0.00073 & 1.219 \\
\hline-5 & 0.001264 & 0.003589 & 0.011558 & $3.191^{\star *}$ & 5 & 0.001191 & -0.00222 & -0.00149 & $-1.981^{\star *}$ \\
\hline-4 & 0.001171 & 0.000645 & 0.012204 & 1.416 & 6 & 0.000978 & 0.000145 & -0.00135 & 1.718 \\
\hline-3 & 0.00118 & 0.004282 & 0.016485 & $3.340^{\star \star}$ & 7 & 0.000918 & 0.000411 & -0.00094 & .784 \\
\hline-2 & 0.001082 & 0.000291 & 0.016776 & .589 & 8 & 0.001036 & 0.001295 & 0.00036 & $2.006^{\star *}$ \\
\hline-1 & 0.001172 & 0.000146 & 0.016922 & .192 & 9 & 0.001079 & -0.00022 & 0.000138 & -.894 \\
\hline 0 & 0.001102 & -0.01525 & 0.001675 & $-2.904^{\star *}$ & 10 & 0.001159 & -0.00219 & -0.00205 & .242 \\
\hline
\end{tabular}

${ }^{* \star}$ denotes Statistical Significance at $5 \%$ level $(p<.05)$ using 2 tailed test.

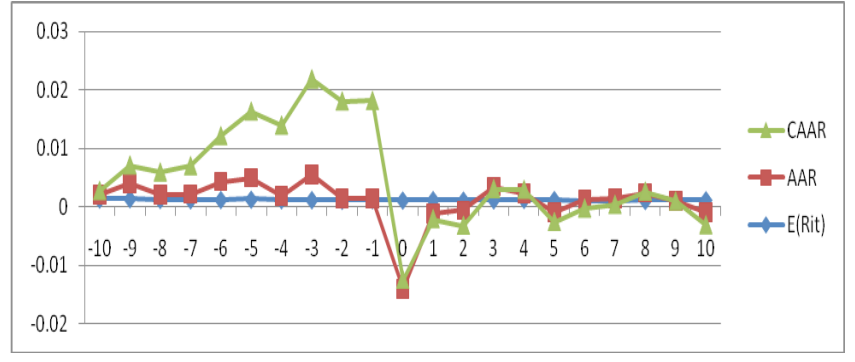

Figure 2. Health sector market reaction to dividend announcement- event study. announcement on stock prices. With higher expectations nearer to the day of announcement stock prices increased there by resulting in higher abnormal returns but with bad news or dividend decreases might be the reason for negative abnormal return.

\subsection{IT Sector}

The Event study conducted for IT Sector indicates that though there is negative AAR and CAAR on $10^{\text {th }}$,

Table 3. Expected return, average abnormal return, cumulative AAR, $t$ test value

\begin{tabular}{|c|c|c|c|c|c|c|c|c|c|}
\hline \multicolumn{5}{|c|}{ Pre Announcement } & \multicolumn{5}{|c|}{ Post Announcement } \\
\hline Days & $E\left(R_{i t}\right)$ & AAR & CAAR & T test & Days & $E\left(R_{i t}\right)$ & AAR & CAAR & T test \\
\hline-10 & 0.001517 & $-1.2 \mathrm{E}-05$ & $-1.2 \mathrm{E}-05$ & -.011 & 0 & 0.00038 & -0.01577 & -0.00451 & $-6.890^{\star \star}$ \\
\hline-9 & 0.001793 & -0.00026 & -0.00027 & -.252 & 1 & 0.001341 & -0.00215 & -0.00667 & $-2.029^{\star \star}$ \\
\hline-8 & 0.000255 & 0.001142 & 0.000869 & 1.041 & 2 & 0.000684 & -0.00236 & -0.00902 & $-2.200^{\star \star}$ \\
\hline-7 & 0.00111 & -0.00088 & $-1.1 \mathrm{E}-05$ & -.768 & 3 & 0.000708 & -0.00104 & -0.01006 & -.977 \\
\hline-6 & 0.001922 & 0.001443 & 0.001432 & 1.347 & 4 & 0.001013 & 0.000349 & -0.00971 & .340 \\
\hline-5 & 0.000558 & 0.002812 & 0.004244 & $2.405^{\star \star}$ & 5 & 0.000799 & -0.00173 & -0.01144 & -1.593 \\
\hline-4 & 0.000336 & 0.000866 & 0.00511 & .636 & 6 & 0.00165 & -0.00028 & -0.01173 & -.260 \\
\hline-3 & 0.000357 & 0.001923 & 0.007033 & 1.500 & 7 & 0.000853 & 0.000949 & -0.01078 & .815 \\
\hline-2 & 0.000803 & 0.003178 & 0.010211 & $2.590^{\star \star}$ & 8 & 0.000596 & -0.00057 & -0.01093 & -.471 \\
\hline-1 & 0.000714 & 0.001046 & 0.011258 & 1.068 & 9 & 0.00056 & 0.000215 & -0.01071 & .197 \\
\hline 0 & 0.00038 & -0.01577 & -0.00451 & $-6.890^{\star \star}$ & 10 & 0.000681 & -0.00123 & -0.01195 & -1.061 \\
\hline
\end{tabular}

${ }^{\star *}$ denotes Statistical Significance at 5\% level $(p<.05)$ using 2 tailed test. 
$9^{\text {th }}$ and $7^{\text {th }}$ day pre announcement, abnormal returns turned positive nearing to the date of announcement with expectation of good news or increased dividend announcement but from the date of announcement onwards, for all the days post announcement returns are negative. This shows dividend announcement does signal and investors do react on the basis of information revealed.

The behavior of CAAR is similar to the AAR during event window. 2 days prior to dividend announcement as well as on the day of announcement and two days post announcement $t$ Test results show statistical significance.

The behavior of Cumulative Abnormal Returns in the Figure 3 reveals initial over reaction from investors and may be considered as the result of breakage of dividend announcement information to the insiders.

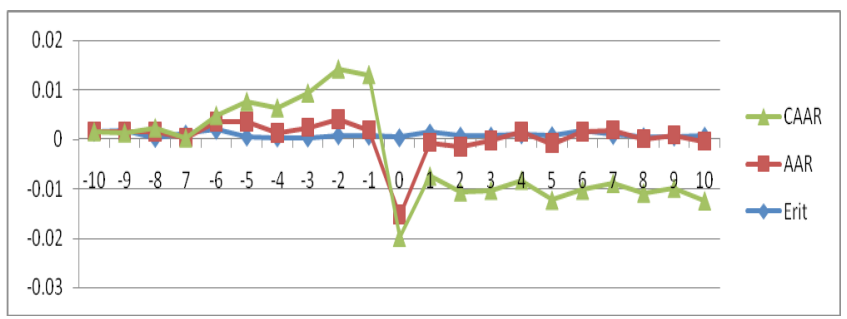

Figure 3. IT sector market reaction to dividend announcement- event study.
The trend had rise nearing the announcement time and a steep fall on the day of announcement and resurfaced on the $1^{\text {st }}$ day post announcement but as a result of higher expectation on the performance of corporate sector CAAR remained negative in the post announcement event window.

\subsection{Realty Sector}

The results of analysis of Realty Sector in the Table 4 reveals, under the Market model the Average Abnormal Returns and Cumulative Average Abnormal Returns are found to be not statistically significant at $10 \%$ level of significance during pre and post event window. Abnormal returns generated nearing dividend announcement turned to be positive with hopes of good news but on the day and post announcement returns are negative. A fall in the CAAR in post event period reflects irrational reaction to the disclosure of dividend announcement information. However, the greatness

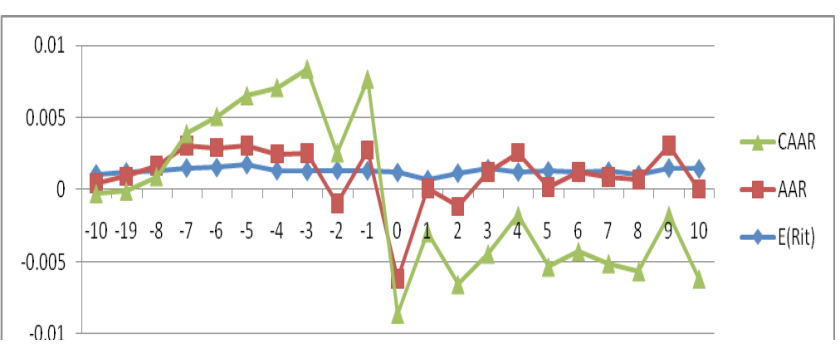

Figure 4. Realty sector market reaction to dividend announcement- event study.

Table 4. Expected return, average abnormal return, cumulative AAR, $t$ test value

\begin{tabular}{|c|c|c|c|c|c|c|c|c|c|}
\hline Event Day & $E\left(R_{i t}\right)$ & AAR & CAAR & T test & Days & $E\left(R_{i t}\right)$ & AAR & CAAR & T test \\
\hline-10 & 0.001086 & -0.00068 & -0.00068 & -.358 & 0 & 0.00119 & -0.00739 & -0.00244 & -2.645 \\
\hline-9 & 0.00122 & -0.00032 & -0.001 & -.180 & 1 & 0.000715 & -0.00063 & -0.00307 & -.376 \\
\hline-8 & 0.001296 & 0.000305 & -0.00069 & .178 & 2 & 0.001147 & -0.00233 & -0.0054 & -1.137 \\
\hline-7 & 0.00149 & 0.001544 & 0.00085 & .774 & 3 & 0.001444 & -0.00025 & -0.00566 & -.135 \\
\hline-6 & 0.001522 & 0.001354 & 0.002203 & .759 & 4 & 0.001223 & 0.001322 & -0.00434 & .686 \\
\hline-5 & 0.001717 & 0.0013 & 0.003503 & .701 & 5 & 0.001297 & -0.00116 & -0.0055 & -.550 \\
\hline-4 & 0.001311 & 0.001134 & 0.004638 & .608 & 6 & 0.001181 & 1.49E-05 & -0.00549 & .008 \\
\hline-3 & 0.001266 & 0.001234 & 0.005872 & .670 & 7 & 0.001283 & -0.00046 & -0.00595 & -.237 \\
\hline-2 & 0.001339 & -0.00233 & 0.003545 & -1.290 & 8 & 0.001049 & -0.00039 & -0.00634 & -.212 \\
\hline-1 & 0.001305 & 0.001409 & 0.004953 & .770 & 9 & 0.001486 & 0.001535 & -0.00481 & .765 \\
\hline 0 & 0.00119 & -0.00739 & -0.00244 & -2.645 & 10 & 0.001429 & -0.0014 & -0.00621 & -.795 \\
\hline
\end{tabular}

${ }^{* *}$ denotes Statistical Significance at $5 \%$ level $(p<.05)$ using 2 tailed test. 
Table 5. Analysis of Variance (ANOVA test - two way without replication)

\begin{tabular}{|c|c|c|c|c|c|c|}
\hline SUMMARY & Count & Sum & Average & Variance & & \\
\hline-10 & 4 & 0.002025 & 0.000506 & $1.31 \mathrm{E}-06$ & & \\
\hline-9 & 4 & 0.003712 & 0.000928 & $3.75 \mathrm{E}-06$ & & \\
\hline-8 & 4 & 0.006634 & 0.001658 & 4.1E-06 & & \\
\hline-7 & 4 & 0.009838 & 0.002459 & $5.8 \mathrm{E}-06$ & & \\
\hline-6 & 4 & 0.017626 & 0.004407 & 9.67E-06 & & \\
\hline-5 & 4 & 0.02523 & 0.006307 & $1.33 \mathrm{E}-05$ & & \\
\hline-4 & 4 & 0.027831 & 0.006958 & $1.25 \mathrm{E}-05$ & & \\
\hline-3 & 4 & 0.036289 & 0.009072 & 2.47E-05 & & \\
\hline-2 & 4 & 0.037972 & 0.009493 & $3.11 \mathrm{E}-05$ & & \\
\hline-1 & 4 & 0.041628 & 0.010407 & $2.55 \mathrm{E}-05$ & & \\
\hline 0 & 4 & -0.0137 & -0.00343 & $1.77 \mathrm{E}-05$ & & \\
\hline 1 & 4 & -0.02046 & -0.00511 & $1.63 \mathrm{E}-05$ & & \\
\hline 2 & 4 & -0.03003 & -0.00751 & 2.09E-05 & & \\
\hline 3 & 4 & -0.03313 & -0.00828 & $5.08 \mathrm{E}-05$ & & \\
\hline 4 & 4 & -0.03155 & -0.00789 & $6.58 \mathrm{E}-05$ & & \\
\hline 5 & 4 & -0.03838 & -0.00959 & $6.43 \mathrm{E}-05$ & & \\
\hline 6 & 4 & -0.03699 & -0.00925 & 5.57E-05 & & \\
\hline 7 & 4 & -0.03546 & -0.00887 & $5.16 \mathrm{E}-05$ & & \\
\hline 8 & 4 & -0.0355 & -0.00887 & $6.34 \mathrm{E}-05$ & & \\
\hline 9 & 4 & -0.03351 & -0.00838 & $6.19 \mathrm{E}-05$ & & \\
\hline 10 & 4 & -0.03816 & -0.00954 & 4.79E-05 & & \\
\hline Banking & 21 & -0.12681 & -0.00604 & 0.000128 & & \\
\hline Healthcare & 21 & 0.088385 & 0.004209 & 4.42E-05 & & \\
\hline IT & 21 & -0.06764 & -0.00322 & $6.06 \mathrm{E}-05$ & & \\
\hline Realty & 21 & -0.03202 & -0.00152 & $1.79 \mathrm{E}-05$ & & \\
\hline \multicolumn{7}{|l|}{ ANOVA } \\
\hline Source of Variation & SS & $d f$ & MS & $F$ & $P$-value & F crit \\
\hline Rows & 0.004251 & 20 & 0.000213 & 16.62991 & $1.69 \mathrm{E}-17$ & 1.747984 \\
\hline Columns & 0.001177 & 3 & 0.000392 & 30.70915 & $3.72 \mathrm{E}-12$ & 2.758078 \\
\hline Error & 0.000767 & 60 & $1.28 \mathrm{E}-05$ & & & \\
\hline Total & 0.006195 & 83 & & & & \\
\hline
\end{tabular}

of overreaction was not significant enough to validate market efficiency statistically.

The Figure 4 depicts that AAR are negative during the entire post event window except on $4^{\text {th }}$ and $9^{\text {th }}$ day from the date of dividend announcement. Similarly, CAAR in pre announcement showed increasing trend but declining trend during the entire post event window. A higher antipode incidence of cumulative abnormal returns in the post announcement is due to the reason of bad news 
and reflects over expectation from investors as a result of dividend decreases.

\subsection{ANOVA Results}

Table 5 present two ways ANOVA output obtained from Microsoft Excel. The total columns in first table represents all 21 days prior and post announcement abnormal return of stock prices and rows represents all the 4 sectors average and variance. We can see higher variance nearing to dividend announcement compared to Post and pre announcement and among four sectors lower variance in IT sector.

At the significance level of 0.05 , to determine evidence of dividend signaling information the null hypothesis is rejected as per the decision rule. The announcement of dividend does impact stock price and shareholders wealth as with 3 degrees of freedom in the denominator and 20 degrees of freedom in the numerator, since, the $\mathrm{F}=30.70915>\mathrm{F}$ Crit $=2.758078$; and as $\mathrm{p}$-value $=3.72 \mathrm{E}-12<0.05$, we reject $H o$. The conclusion is drawn that analysis gives sufficient statistical evidence of stock market efficiency to react to the dividend signaling and impact on stock price during dividend announcement.

\section{Conclusion}

The study of the abnormal returns on announcement of dividend resulted in general conclusion describing it as significant. The empirical evidence depicts that dividend announcement information does impact share prices supporting the EMH as the t-test value on AAR for portfolio shows that during the event window they are statistically significant at 5\% level for Banking, Healthcare and IT Sector, though we couldn't validate statistically for Realty Sector. Also, ANOVA results clearly indicate statistical significance.

The findings of Indian capital market reaction to dividend announcements strongly support the information content of the dividend hypothesis. The results further support the semi-strong form of the efficient capital market hypothesis as documented by Fama (1970) that on average, the stock market adjusts in an efficient manner to new dividend announcement information.
Almost all of the price adjustment occurred within day dividend announcement ( 0 day) or nearing the event based on the information revealed by the dividend event announcement. The results also confirm that market participant expectations have a significant influence on abnormal returns of dividend announcement. Our study contributes as an addition to the finance literature and holds statistical significance similar to many other event studies on dividend signaling and its impact on the shareholders wealth. The future research in the area of dividend announcements on shareholders wealth can be focused on examining dividend increase and decrease impact separately on shareholders wealth.

\section{References}

Aamir \& Shah. (2011). Dividend announcements and the abnormal stock returns for the event firm and its rivals. Australian Journal of Business and Management Research, 1(8), 72-76.

Aharony \& Swary, I. (1980). Quarterly dividend and earnings announcements and Stockholders' returns: An empirical analysis. Journal of Finance, 35, 1-12. https:// doi.org/10.1111/j.1540-6261.1980.tb03466.x

Amihud, Y. \& Li, K. (2002). The declining information content of dividend announcements and the effect of institutional holdings, NYU, working paper.

Asquith, P., \& David, W. M. Jr. (1983). The Impact of initiating dividend payments on Shareholders wealth, Journal of Business 56, 77-96. https://doi.org/10.1086/296187

Bajaj, M. \& Vijh, A. (1990). Dividend clienteles and the information content of dividend changes. Journal of Financial Economics, 26, 193-219. https://doi.org/10.1016/0304-405X(90)90003-I

Bhattacharya,S.(1979).Imperfectinformation, dividendpolicy, and the bird in the hand fallacy. Bell Journal of Economics, 52, 1007-1034 https://doi.org/10.2307/3003330

Black, F. (1976). The dividend puzzle. Journal of Portfolio Management, 2, 5-8. https://doi.org/10.3905/ jpm.1976.408558

Black, F., \& Myron, S. S. (1974). The effects of dividend yield and dividend policy on common stock prices and returns, Journal of Financial Economics, 1, 1-22. https:// doi.org/10.1016/0304-405X(74)90006-3

Brickley, J. (1983). Shareholder wealth, information signaling and the specially designated dividend. Journal of Financial Economics, 12, 187-209. https://doi. org/10.1016/0304-405X(83)90035-1 
Brook, Y., Charlton W. T., Jr. \& Hendershott R. J. (1998). Do firms use dividends to signal large future cash flow increases? Financial Management, 27(3), 46-57. https:// doi.org/10.2307/3666274

DeAngelo, H., DeAngelo, L., \& Douglas, J. S. (1996) Reversal of fortune: Dividend signaling and the disappearance of sustained earnings growth, Journal of Financial Economics, 40, 341-371. https://doi.org/10.1016/0304405X(95)00850-E

Deeptee, B., Roshan. (2009). Signalling power of dividend on firms' future profits - a literature review. Evergreen Energy - International Interdisciplinary Journal, New York.

Dhillon, U. S. \& Herb J. (1994). The effect of dividend changes on stock and bond prices. Journal of Finance. 49(1), 281-289. https://doi.org/10.1111/j.15406261.1994.tb04430.x

Doron, N., \& Amir, Z. (2001) Dividend changes and future profitability, Journal of Finance, 56(6), 2111-2133. https://doi.org/10.1111/0022-1082.00400

Eades, K., Hess, P., \& Kim, H. (1985). Market rationality and dividend announcements, Journal of Financial Economics, 14, 581-604. https://doi.org/10.1016/0304405X(85)90027-3

Fama \& Kenneth, F. (2000). Forecasting profitability and earnings, Journal of Business, 73, 161-175. https://doi. org/10.1086/209638

Hashemijoo M., Ardekani A. M., \& Younesi N. (2012). The impact of dividend policy on share price volatility in the malaysian stock market. Journal of Business Studies Quarterly, 4(1), 111-129.

Healy, P. M., \& Krishna G. P. (1988). Earnings information conveyed by dividend initiations and omissions. Journal of Financial Economics, 21, 149-175. https://doi. org/10.1016/0304-405X(88)90059-1

Howe, J. S., \& Shen Y. P. (1998). Information associated with dividend initiations: Firm specific or industrywide? Financial Management, 27(3), 17-26. https://doi. org/10.2307/3666271

Husam, Michael, Pillai. (2010). Dividend policy: A review of theories and empirical evidence. International Bulletin of Business Administration, 171-200.

Jensen G. R., \& Johnson J. M. (1995). The dynamics of corporate dividend reductions. Financial Management, 24(4), 31-51. https://doi.org/10.2307/3665949

Jensen, G., Donald, R., Solberg, P., \& Zorn, T. S. (1992). Simultaneous determination of insider ownership, debt and dividend policies. Journal of Financial and Quantitative Analysis, 27(2), 247-263. https://doi.org/10.2307/2331370

John, K., \& Lang L. H. P. (1991). Insider trading around dividend announcements: theory and evidence. Journal of
Finance, 46, 1361-1389. https://doi.org/10.1111/j.15406261.1991.tb04621.x

Kalay, A. (1982). The ex-dividend day behavior of stock prices: a re-examination of the clientele effect. Journal of Finance, 37(4), 1059-1070. https://doi.org/10.1111/ j.1540-6261.1982.tb03598.x

Kalay,A., \& Uri, L. (1985). Predictable events and excess returns: The case of dividend announcements. Journal of Financial Economics, 14, 423-449. https://doi.org/10.1016/0304-405X(85)90007-8

Kanwal, A., \& Kapoor, S. (2008). Relevance of Signaling and Smoothing Approaches to Dividend: A study of Indian IT Sector. Asia Pacific Business Review. 4(4).

Kanwal, A., Kanwal, \& Kapoor, S. (2008). Determinants of Dividend Payout ratios- A study of Indian information technology sector. International Research Journal of Finance and Economics, 15, 63-71.

Kent B. H., Farrelly G. E., \& Edelman R. B. (1985). A survey of management views on dividend policy. Financial Management, 14, 78-84 https://doi. org/10.2307/3665062

Laux, P., Starks L. T., \& Yoon P. S. (1998). The relative importance of competition and contagion in intra-industry information transfers: An investigation of dividend announcements. Financial Management, 27(3), 5-16. https://doi.org/10.2307/3666270

Lintner, J. V. (1956). Distribution of incomes of corporations among dividends, retained earnings, and taxes. American Economic Review, 46, 97-113.

Miller, M. H., \& Modigliani F. (1961). Dividend policy, growth and the valuation of shares. Journal of Business, 34(4), 411-33. https://doi.org/10.1086/294442

Miller, Merton H., \& Kevin, R. (1985). Dividend policy under asymmetric information. Journal of Finance, 40, 1031-1051. https://doi.org/10.1111/j.1540-6261.1985. tb02362.x

Modigliani, F. (1982). Debt, dividend policy, inflation and market valuation. Journal of Finance, 37, 255-73. https:// doi.org/10.1111/j.1540-6261.1982.tb03549.x

Nissim, D., \& Amir Z. (2001). Dividend changes and future profitablility. Journal of Finance, 56(6), 21112133. https://doi.org/10.1111/0022-1082.00400

Pettit, R. R. (1972). Dividend announcements, security performance and capital market efficiency. Journal of Finance, 27, 993-1007. https://doi.org/10.1111/j.15406261.1972.tb03018.x

Purnanandam, J. \& Hanumantha Rao, K. S. (1966). Corporate dividends and target payout ratios in the indian cotton textile industry 1946-1963. Journal of Industrial Economics, 15(1), 38-43 https://doi.org/10.2307/2097847 
Rane, A., \& Raju, A. (2016). Impact of dividend announcement on stockholder's return - an empirical analysis of Indian healthcare sector. Doctoral Research Conference in Business Studies and Social Sciences (DR16 India Conference) ISBN: 978-1-943579-60-0 Chennai-India. 2 April, 2016. Paper ID: DRC610, pp. 1-15.

Rozeff, M. S. (1982). Growth, beta and agency costs as determinants of dividend payout ratios. Journal of Financial Research. 5(3), 249-259. https://doi.org/10.1111/j.14756803.1982.tb00299.x

Saravanakumar \& Mahadevan. (2010). Dividend announcement impact on Indian Bourses. International Journal of Enterprise and Innovation Management Studies, 1(3).

Strong, N. (1992). Modelling abnormal returns: a review article. Journal of Business, Finance and Accounting, 19(4), 533-53. https://doi.org/10.1111/j.1468-5957.1992. tb00643.x
Travlos, N., Trigeorgis L., \& Vafeas N. (2001). Shareholder wealth effects of dividend policy changes in an emerging stock market: the case of Cyprus. Multinational Finance Journal, 5(2). 87-112. https://doi.org/10.17578/5-2-1

Walter, J. E. (1956). Dividend polices and common stock prices. The Journal of Finance, 16, 29-41. https://doi. org/10.1111/j.1540-6261.1956.tb00684.x

Watts, R.(1973). The information content of dividends. Journal of Business, 46(2), 191-211. https://doi.org/10.1086/295525

Woolridge, J. R. (1983). Dividend changes and security prices. Journal of Finance, 38, 1607-1615. https://doi. org/10.1111/j.1540-6261.1983.tb03844.x

Yoon, P., \& Starks, L. (1995). Signaling, investment opportunities, and dividend announcements. Review of Financial Studies, 8, 995-1018. https://doi.org/10.1093/rfs/8.4.995 